\title{
COMPARISON WITH HUMAN AMNIOTIC MEMBRANE- AND ADIPOSE TISSUE-DERIVED MESENCHYMAL STEM CELLS
}

\author{
In Seob Hwang, MD, Hwi Gon Kim, MD, Deok Hyeon Jo, MD, Dong Hyung Lee, MD, Yun Hee Koo, MD, \\ Yong Jung Song, MD, Yong Jin Na, MD, Ook Hwan Choi, MD \\ Department of Obstetrics and Gynecology, Pusan National University School of Medicine, Busan, Korea
}

\section{Objective}

Mesenchymal stem cells (MSC) have been considered as an ideal source of stem cells because of low immunogenicity and availability of autologous cells. Although it has been reported that amniotic membrane contains MSC, the difference between amniotic membrane-derived mesenchymal stem cells (AMSC) and MSC isolated from other tissues is still not clear. This study was designated to compare the characteristics and gene expression profile of human AMSCs (hAMSC) and adipose tissue-derived mesenchymal stem cells (hADSC).

\section{Methods}

MSC were cultured from human amniotic membranes and adipose tissue by enzyme digestion. We compared the growth rate, surface marker expression, differentiation potential to adipogenic and osteogenic lineages, and gene expression of hAMSC with those of hADSC.

\section{Results}

hAMSC had growth rate and surface marker expression similar with hADSC. However, cyclopamine inhibited hAMSC proliferation in a dose-dependent manner without affecting hADSC proliferation. hAMSC showed lower differentiation potential to adipogenic and osteogenic lineages and lower in vivo tumor growth promoting effect in lung cancer cells xenotransplantion model of nude mouse than hADSC. Gene expression analysis using microarray revealed that many genes to be expressed differentially between hAMSC and hADSC are related to development and differentiation processes.

\section{Conclusion}

These findings indicate that hAMSC have different characteristics with hADSC, and that to use MSC isolated from different sources according to therapeutic purposes may provide more promising results in clinical trials than general use of MSC from a specific source.

Keywords: Mesenchymal stem cells; Human amniotic membrane-derived mesenchymal stem cells; Human adipose tissue-derived mesenchymal stem cells

줄기세포는 자가증식이 가능하며 어떤 환경이 주어지면 신경세포나 상피세포, 심근세포, 췌장세포 등 다양한 세포로 분화할 수 있어, 신체 의 어떤 조직이나 장기에 질병이 생겼을 때 줄기세포로부터 분화된 같 은 종류의 세포로 병든 세포를 대체하여 다양한 난치성 질환을 치료하 는 것이 새로운 의학기술로 제시되고 있다.

중간엽줄기세포(mesenchymal stem cells)는 골수에서 처음 분리되 었고 생체 외에서 비교적 쉽게 증식가능하며 다양한 세포로 분화 가능 한 성체줄기세포의 하나이다[1-3]. 중간엽줄기세포의 분화능은 지방세 포, 골모세포, 연골세포 등 중배엽성 조직뿐만 아니라[4] 간세포 등 내 배엽성세포[5], 신경세포[6] 등 외배엽성 세포로도 분화가 가능하다. 이
Received: 2011. 3.22. Revised: 2011. 9. 9. Accepted: 2011. 9.15. Corresponding author: Ook Hwan Choi, MD

Department of Obstetrics and Gynecology, Pusan National University Yangsan Hospital, Beomeo-ri, Mulgeum-eup, Yangsan 626-770, Korea

Tel: +82-55-360-2580 Fax: +82-55-360-2160

E-mail: ohchoi@pusan.ac.kr

This is an Open Access article distributed under the terms of the Creative Commons Attribution Non-Commercial License (http://creativecommons.org/licenses/ by-nc/3.0/) which permits unrestricted non-commercial use, distribution, and reproduction in any medium, provided the original work is properly cited.

Copyright $\odot$ 2011. Korean Society of Obstetrics and Gynecology 


\section{KOREAN JOURNAL OF OBSTETRICS \& GYNECOLOGY}

In Seob Hwang, et al. Comparison with human amniotic membrane- and adipose tissue-derived mesenchymal stem cells

러한 특성은 중간엽줄기세포가 조직재생 및 세포치료를 위한 유망한 세포공급원으로 사용될 수 있음을 의미한다. 인체중간엽줄기세포는 골 수에서 처음 보고된 이래, 지방조직을 포함한 뇌, 비장, 간, 신장, 폐, 골 수, 근육, 흉선, 췌장 등 다양한 조직에 존재하고 있음이 보고되었다. 중 간엽줄기세포는 기본적으로 유사한 특성을 나타내나[7], 서로 다른 조 직에서 분리한 중간엽줄기세포가 다른 특성을 나타냄도 보고되고 있다 [8-10].

인체 태반의 태아부분은 양막 및 융모막으로 구성되며 이중 양막은 상 피조직과 기저막 및 기질부로 구성되어 있다. 최근 양막에 중간엽줄기세 포를 포함한 다양한 종류의 줄기세포가 존재함이 보고되고 있는데[11], 이들 세포가 유사간세포로 분화 가능하고[12], 지방조직유래 중간엽줄기 세포와 유사한 면역조절 작용을 나타냄이 보고되어[13], 양막유래 중간 엽줄기세포와 성체조직유래 중간엽줄기세포가 유사한 특성을 가짐을 제 시하였다. 그러나, 양막유래 중간엽줄기세포가 다른 조직유래 중간엽줄 기세포와 동일한 특성을 세포인지는 아직 명확히 밝혀져 있지 않다.

본 연구에서는 양막유래 중간엽줄기세포(human amniotic membrane-derived mesenchymal stem cells, hAMSC)와 성체조 직인 지방조직유래 중간엽줄기세포(human adipose tissue-derived mesenchymal stem cells, hADSC)의 증식 및 분화특성, 암성장 증식효 과와 유전자 발현을 비교분석 하였다.

\section{연구대상 및 방법}

\section{1. 중간엽줄기세포의 배양}

지방조직으로부터 중간엽줄기세포를 분리하기 위하여 성형외과에 서 피하지방 제거술을 시행한 환자로부터 동의하에 지방조직을 얻었 다. 분리한 지방조직은 Hank's balanced salt solution (HBSS)로 세척 후 지방조직을 얇게 자른 다음 $0.075 \%$ collagenase (Sigma, St. Louis, MO, USA)를 첨가한 $10 \%$ 소태아혈청(fetal bovine serum, FBS)을 포함 한 $\alpha$-Minimum essential medium eagle (MEM) 배지로 현탁하여 $37^{\circ} \mathrm{C}$, $5 \% \mathrm{CO}_{2}$ 농도의 조건하에서 30 분간 처리하였다. 원심분리 후 pellet에 $10 \%$ FBS를 포함한 a-MEM 배지를 사용하여 중간엽줄기세포를 배양 하였다.

환자동의하에 획득한 태반조직으로부터 양막을 분리하고 양막 조직 을 잘게 자른 후 $0.05 \%$ trypsin과 $0.53 \mathrm{mM}$ ethylenediaminetetraacetic acid (EDTA)로 처리하여 세포를 분리하고 15\% FBS와 $5 \mathrm{ng}$ 표피성장 인자(epidermal growth factor, EGF) 를 함유한 $\alpha-M E M$ 배지에서 배양 한다. 세포가 70-80\%까지 증식한 후 trypsin/EDTA로 처리하여 세포를 단일세포로 분리하고 해당배지에서 각 세포를 계대 배양하였다. 실험 에는 3-5회 계대 배양한 세포를 사용하였다.

\section{2. 유세포분석}

배양한 세포에서 표면항원의 발현을 확인하기 위하여 유세포분석 을 실시하였다. 유세포분석을 위하여 세포를 72 시간 배양한 후 $0.25 \%$
trypsin/EDTA로 세포를 분리한 후 $4 \%$ formaldehyde로 30 분간 고정 시킨다. 고정된 세포는 flow cytometry buffer $(1 \times$ phosphatebuffered saline, $2 \%$ fetal bovine serum [FBS], 0.05\% sodium azide)로 씻어 주고 106세포로 나눠 담은 뒤 CD29, CD31, CD34, CD44, CD45, CD90, CD105, HLA-DR (Becton Dickinson Biosciences, San Jose, CA, USA) 항체를 포함하는 flow cytometry buffer로 각각 처리하였다. 각 항체의 isotype immunoglobulin을 대조군으로 사용하였다. 항체로 처리된 세포는 FACScan argon laser cytometer (Becton Dickinson Biosciences)를 이용하여 측정하였다.

\section{3. 증식능 및 생존능의 측정}

6 well 배양용기에 중간엽줄기세포를 10,000 개를 깔고 일정시간 후 현미경으로 haematometer를 사용하여 세포 수를 측정하였고 세포 의 생존능은 trypan blue exclusion 방법으로 다음과 같이 측정하였다. $0.4 \%$ trypan blue와 cell suspension을 1:1로 섞어 10-15분이 지난 후 hemocytometer로 푸르게 염색되지 않는 세포들을 살아있는 세포수 로 집계하였다.

\section{4. 중간엽줄기세포의 지방 및 골세포로의 분화유도}

중간엽줄기세포의 지방 및 골세포로의 분화를 유도하기 위해서 지 방세포유도 분화배지(10\% FBS, $1 \mu \mathrm{M}$ dexamethasone, $0.5 \mathrm{mM}$ 3-isobutyl-1-methylxanthine, $200 \mu \mathrm{M}$ indomethacin 포함한 $\alpha$-MEM) 및 골세포유도 분화배지(10\% FBS, $0.1 \mu \mathrm{M}$ dexamethasone, $10 \mathrm{mM}$ $\beta$-glycerophosphate, $50 \mu \mathrm{M}$ ascorbic acid 포함한 $\alpha-\mathrm{MEM})$ 에서 각 각 10 일 및 21 일동안 배양하였으며, 배지는 3 일에 한 번씩 교환하였 다. 분화된 지방세포는 세포표면에 축적된 lipid를 oil red O로 염색하고, 여기에 isopropyl alcohol을 처리한 후 $510 \mathrm{~nm}$ 에서 흡광도를 측정하여 정량하였다. 분화된 골세포는 alizarin red $\mathrm{S}$ 로 염색한 후 Meta Morph 프로그램(Molecular Devices, LLC., Sunnyvale, CA, USA)을 이용하여 전체 세포에서 분화된 세포의 \%를 측정 수치화하여 정량하였다.

\section{5. 종양성장 촉진능 측정}

중간엽줄기세포의 종양성장 촉진여부를 측정하기 위하여 생후 7 주 의 Balb/C nude mouse에 피하로 폐암세포주인 H460세포 $1 \times 10^{5}$ 개 를 주사하고 이와 동시에 $1 \times 10^{6}$ 의 hAMSC와 hADSC나 HBSS를 좌심 실로 주사하였다. 2주 후 동물을 희생시켜 피하에 형성된 종양의 무게 를 측정하였다.

\section{Expression microarray 분석}

hAMSC와 hADSC의 유전자 분석을 위해서 서로 다른 두 개의 양 막과 지방조직에서 total RNA를 RNeasy mini kit (QIAGEN, Inc, Valencia, CA, USA)로 분리하고 Macrogen (Seoul, Korea)에 의뢰 하여 48,095개의 probe를 포함하는 Illumina expression bead chip (Sentrix Human-6-V2, Illumina Inc., San Diego, CA, USA)으로 유전 자 발현을 분석하였다. 


\section{7. 통계분석}

각 실험군 간의 통계학적 차이는 Student's $t$-test를 이용하였으며, 통계학적으로 유의성이 있는 $P$ 수치는 0.05 미만으로 하였다.

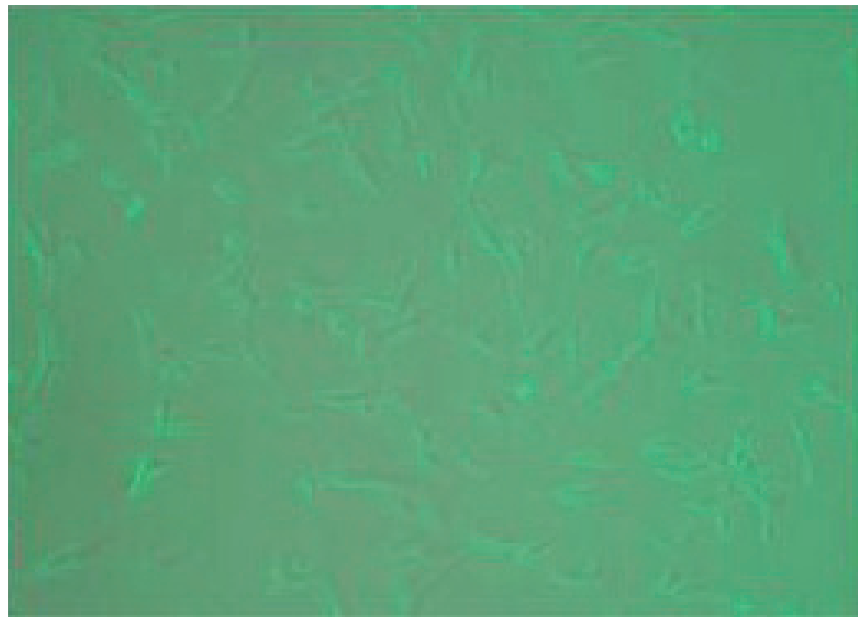

hADSC
결 과

\section{1. 표면항원의 발현}

hAMSC와 hADSC는 섬유모세포의 형태로 증식하였으며, 두 세포 간 에 형태학적인 유의한 차이는 나타나지 않았다(Fig. 1). 두 군 세포의

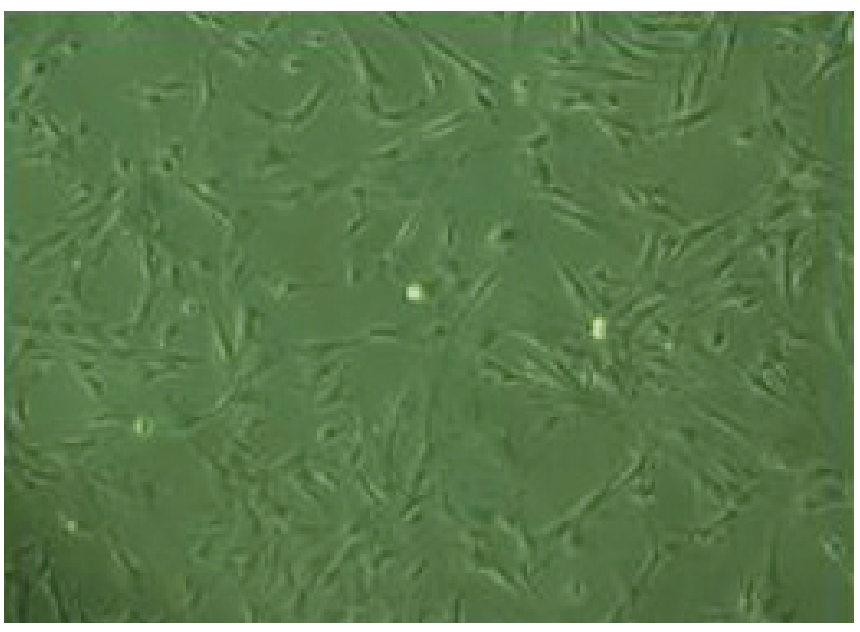

hAMSC

Fig. 1. The cell morphology hAMSC and hADSC. Photographs were taken under phase microscope $(\times 100)$. hAMSC, human amniotic membrane-derived mesenchymal stem cells; hADSC, human adipose tissue-derived mesenchymal stem cells.

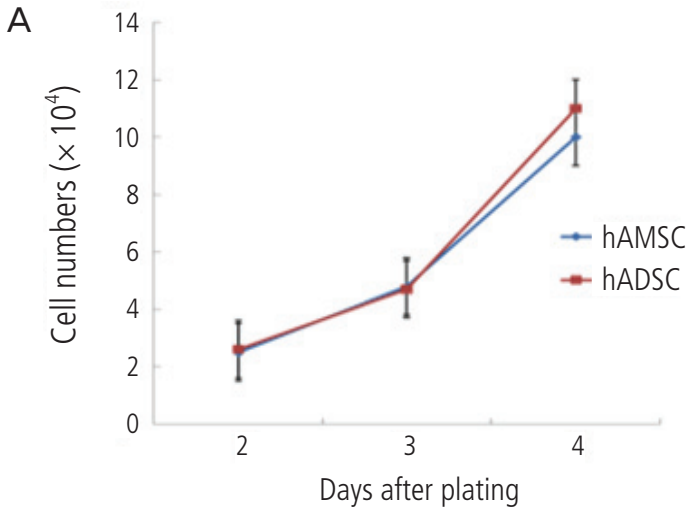

B

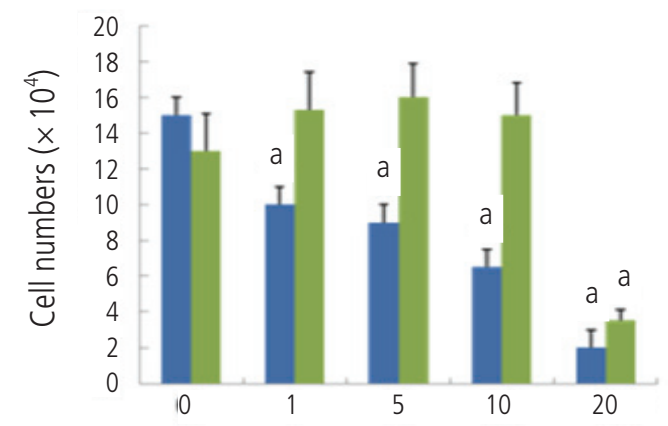

Fig. 2. (A) Proliferation of hAMSC and hADSC. (B) Effect of cyclopamine on the proliferation of hAMSC and hADSC. Cell number was determined 5 days after plating of cells in the presence or absence of cyclopamine. Data represent mean \pm standard error of mean (SEM) of three different experiments. (C) Effect of cyclopamine on the viability of hAMSC and hADSC. Cell viability of hAMSC and hADSC in the absence or presence of cyclopamine was determined on days 4 by trypan blue exclusion assay. Data represent mean \pm SEM of three different experiments. hAMSC, human amniotic membrane-derived mesenchymal stem cells; hADSC, human adipose tissue-derived mesenchymal stem cells. ${ }^{a} P<0.05$ compared with the data in the absence of cyclopamine.

C

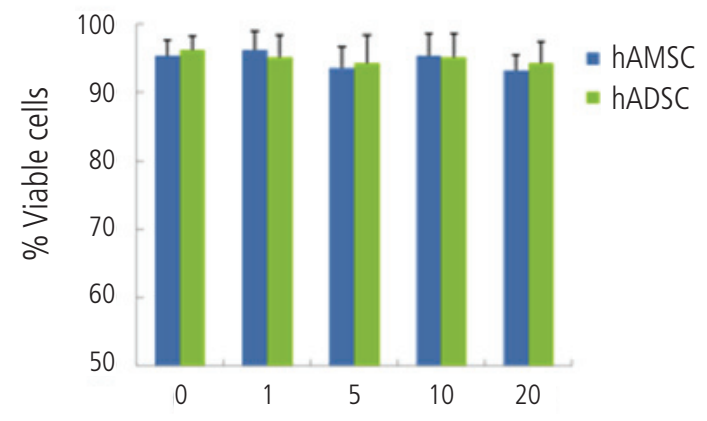

Cyclopamine (mM) 


\section{KOREAN JOURNAL OF OBSTETRICS \& GYNECOLOGY}

In Seob Hwang, et al. Comparison with human amniotic membrane- and adipose tissue-derived mesenchymal stem cells

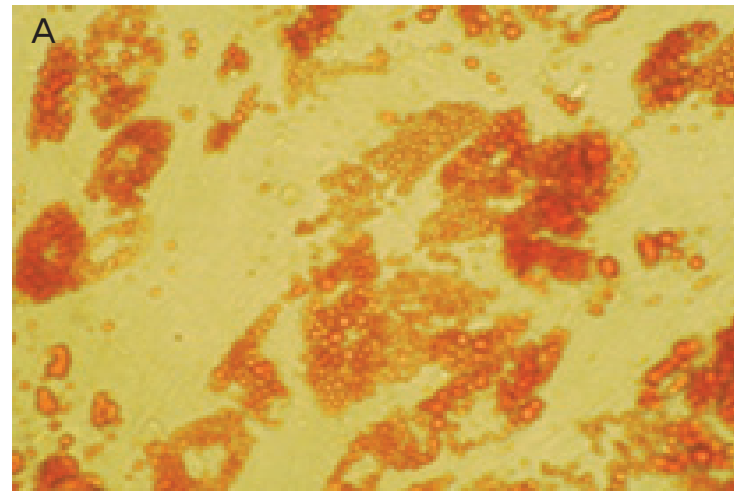

hADSC

B

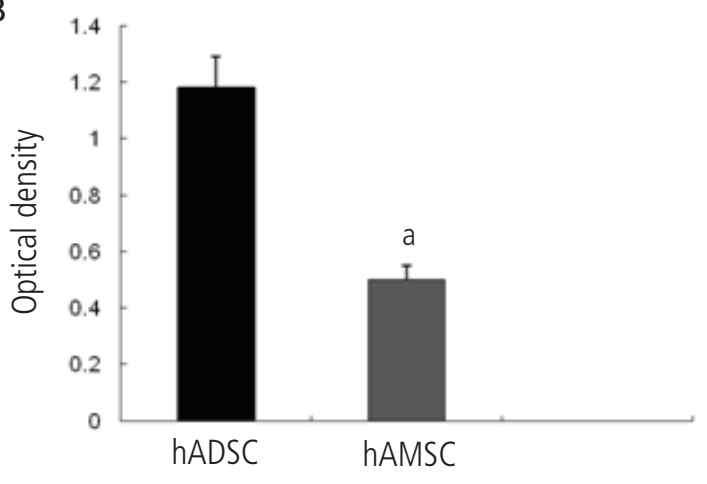

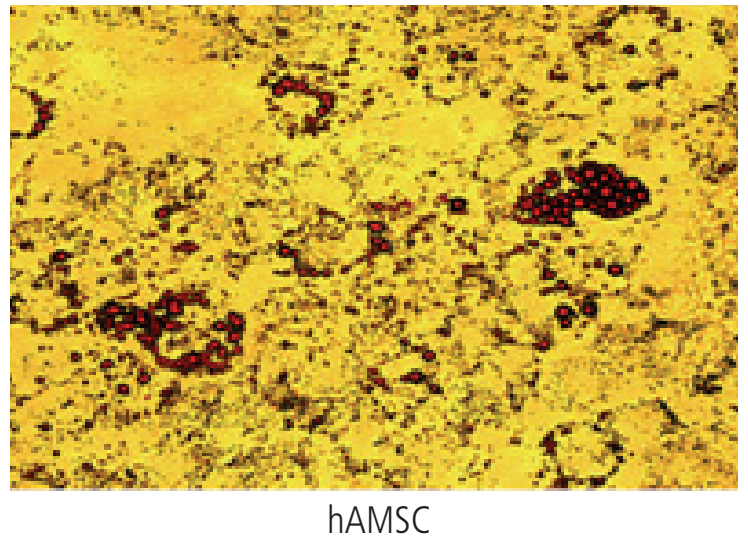

Fig. 3. Adipogenic differentiation of hAMSC and hADSC. (A) Cells were grown to confluence and then induced to osteogenic or adipogenic differentiation in differentiation media. Adipogenic differentiation (AM) was determined with Oil Red 0 staining as an indicator of intracellular lipid accumulation $(\times 200)$. (B) The quantitation of adipogenic differentiation was performed by measurement of optical density in isopropanol extract of oil red 0 staining. Data represent mean \pm SEM of three different experiments. hAMSC, human amniotic membrane-derived mesenchymal stem cells; hADSC, human adipose tissue-derived mesenchymal stem cells. ${ }^{a} P<0.05$ compared with hADSC.

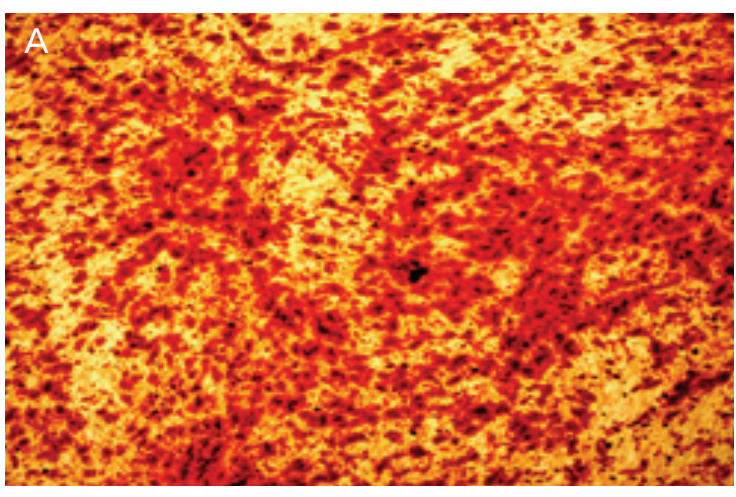

hADSC

B

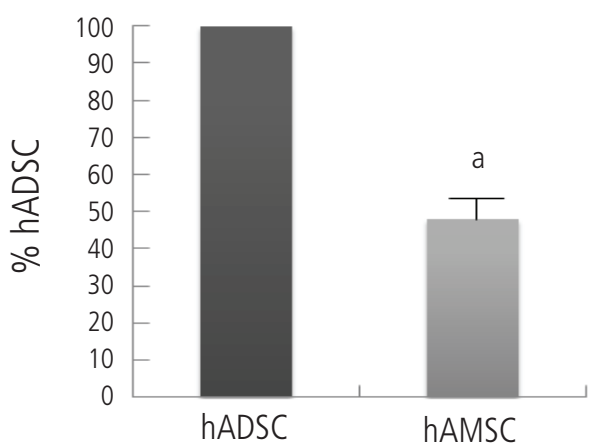

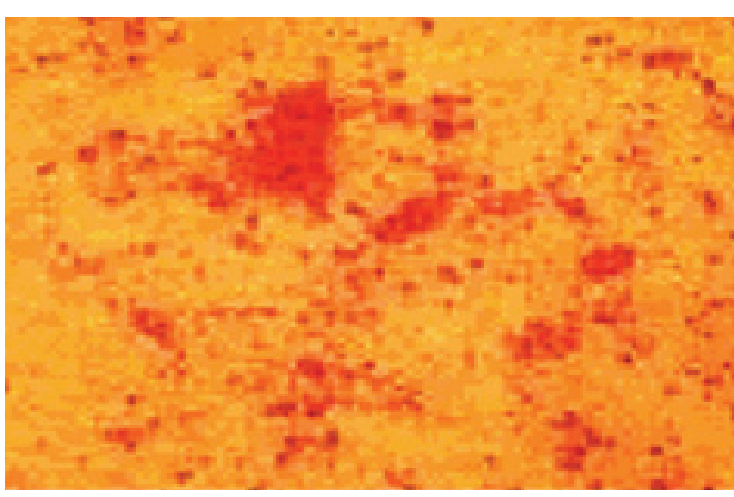

hAMSC

Fig. 4. Osteogenic differentiation of hAMSC and hADSC. Cells were grown to confluence and then induced to osteogenic differentiation in differentiation media. (A) Osteogenic differentiation (OM) was determined by calcification deposits on the cell monolayer, which were stained with alizarin red S Alizarin Red S. (×200). (B) The quantitation of osteogenic differentiation was performed by determination of density and area of Alizarin Red S staining with an image analysis program (Metamorph, Molecular Devices, LLC., Sunnyvale, (A, USA). Data represent mean \pm standard error of mean of three different experiments. hAMSC, human amniotic membrane-derived mesenchymal stem cells; hADSC, human adipose tissue-derived mesenchymal stem cells. ${ }^{a} P<0.05$ compared with hADSC. 
Table 1. Expression of surface markers in hADSC and hAMSC

\begin{tabular}{|lrr|}
\hline & hAMSC & \multicolumn{1}{c|}{ hADSC } \\
\hline CD29 & $96.2 \pm 2.3$ & $95.2 \pm 3.3$ \\
CD90 & $98.7 \pm 1.7$ & $97.7 \pm 2.7$ \\
CD105 & $95.2 \pm 0.4$ & $94.6 \pm 1.5$ \\
CD44 & $98.1 \pm 1.8$ & $96.1 \pm 3.1$ \\
CD31 & $1.2 \pm 0.4$ & $1.5 \pm 0.8$ \\
CD34 & $1.6 \pm 0.2$ & $1.2 \pm 0.5$ \\
CD45 & $1.4 \pm 0.5$ & $1.7 \pm 0.2$ \\
HLA-DR & $1.7 \pm 0.6$ & $1.4 \pm 0.3$ \\
\hline
\end{tabular}

Data represent mean \pm standard error of mean ( $n=4$ per group).

hAMSC, human amniotic membrane-derived mesenchymal stem cells; hADSC, human adipose tissue-derived mesenchymal stem cells.

특성비교를 위하여 유세포분석으로 표면항원의 발현을 측정하였다. 중 간엽줄기세포의 표면항원으로 알려진 CD29, CD44, CD90, CD105 등 은 두 군 세포에서 모두 높게 발현되었으며 유의한 차이가 확인되지 않 았다. 또한, 혈구세포의 표면항원인 $\mathrm{CD} 34, \mathrm{CD} 45$ 와 내피세포의 표지자 인 CD31, 주조직적합항원인 human leukocyte antigen-DR (HLA-DR) 은 두 군 세포 모두에서 발현이 되지 않았다(Table 1).

\section{2. 세포증식에 대한 Cyclopamine의 영향}

hAMSC와 hADSC의 증식능을 배양 5일 후 세포수 측정으로 비교 한 결과 두 군 세포사이의 유의한 차이가 관찰되지 않았다(Fig. 2A). 골 수유래 중간엽줄기세포의 증식을 촉진하는 것으로 알려진[14] Sonic hedgehog (Shh)의 세포증식에 대한 효과를 측정하기 위하여 Shh 의 억제제[15]인 cyclopamine의 영향을 관찰하였다. hAMSC에서는 세포증식이 cyclopamine처리에 의해 농도의존적으로 감소하였으나 hADSC는 오직 $20 \mathrm{mM}$ 에서 세포증식이 억제되었다(Fig. 2B). Trypan blue 분석으로 약물처리 4일 후 세포생존에 대한 영향을 측정한 결과 cyclopamine은 두 군 세포에서 세포생존능에는 유의한 차이가 없었다 (Fig. 2C).

\section{3. 분화능의 비교}

hAMSC와 hADSC의 지방세포로의 분화능을 비교하기 위하여 두 군 의 중간엽줄기세포를 지방분화배지로 10 일간 배양하고 분화정도를 oil red O 염색으로 비교하였다. hADSC에 비하여 lipid droplet의 크기 가 적어 지방세포로의 분화능이 hAMSC에서 낮았다(Fig. 3). hAMSC 와 hADSC의 골모세포로의 분화능을 비교하기 위하여 두 군의 중간엽 줄기세포를 골모세포 분화배지로 3주간 배양하고 분화정도를 Alizarin Red S염색으로 비교하였다. 세포외기질에 $\mathrm{Ca}^{2+}$ 침착의 정도가 hADSC 에 비하여 hAMSC에서 현저히 낮음이 관찰되었다(Fig. 4).

\section{4. 생체 종양성장 촉진능 비교}

hADSC는 종양성장 촉진능을 가지고 있음이 보고되고 있다[16,17].

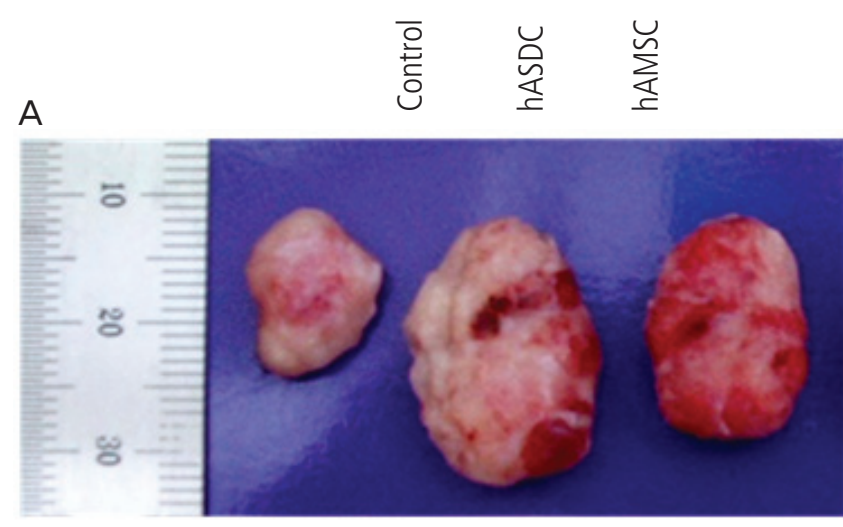

B

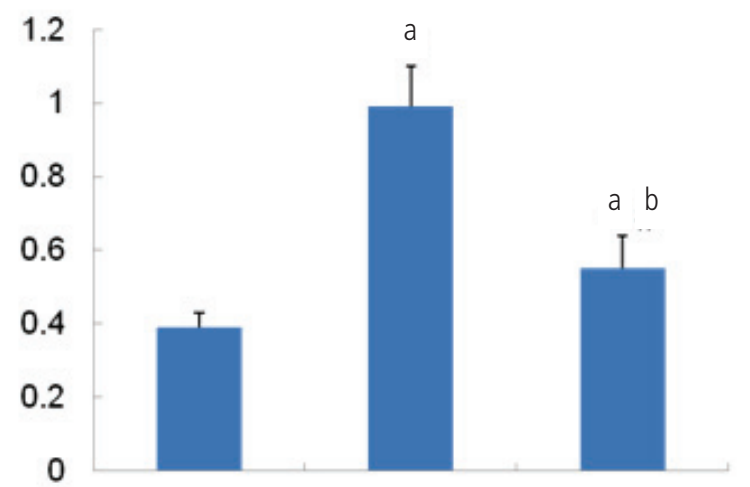

Fig. 5. Effects of hAMSC and hADSC injection on the tumor growth in vivo. (A) Effect of hASCs cotransplantation on tumor growth from xenotransplanted H460 cells. H460 (1×105) were injected subcutaneously and $1 \times 106$ hADSC or hAMSC were injected into left ventricle. Representative photograph of H460-derived tumors in nude mice on 14 days after transplantation. (B) Quantification of tumor weights. Data represent mean \pm standard error of mean $(n=4)$. hAMSC, human amniotic membrane-derived mesenchymal stem cells; hADSC, human adipose tissue-derived mesenchymal stem cells. ${ }^{a} P<0.05$, significant difference from control data of $\mathrm{H} 460$ alone; ${ }^{b} P<0.05$, significant difference from $\mathrm{H} 460+$ hADSC group.

중간엽줄기세포의 종양성장 촉진효과를 관찰하기 위하여 100,000 개 의 폐암세포주(H460) 세포를 nude mouse의 피하에 이식하고 좌심실 로 hAMSC와 hADSC를 주입하였다. 2주 후 형성된 종양을 제거하여 비교한 결과 hADSC에서 현저한 종양형성의 증가가 나타났다. hAMSC 주입 시도 종양의 크기가 증가하였으나 그 촉진효과는 hADSC에 비하 여 낮았다(Fig. 5).

\section{5. 유전자 발현분석}

hAMSC와 hADSC의 유전자 발현을 microarray로 분석하였다. 각 조 직 당 2 개의 서로 다른 시료에서 분리한 중간엽줄기세포의 mRNA 발 현을 microarray로 분석하고 두 시료에서 공통으로 변화하는 유전자 를 확인한 결과 hAMSC에서 327 개의 유전자가 감소하였고 331개 의 유전자가 증가하였다. 이들 중 가장 많이 변화한 유전자의 목록을 Tables 2, 3에 표시하였다. 발현차이가 관찰된 유전자의 목록을 DAVID 


\section{KOREAN JOURNAL OF OBSTETRICS \& GYNECOLOGY}

In Seob Hwang, et al. Comparison with human amniotic membrane- and adipose tissue-derived mesenchymal stem cells

Table 2. Genes list down-regulated in hAMSC than in hADSC

\begin{tabular}{|c|c|c|c|}
\hline Definition & Fold & Definition & Fold \\
\hline $\begin{array}{l}\text { Ectonucleotide Pyrophosphatase/phosphodiesterase } 2 \\
\text { (autotaxin) (ENPP2), mRNA }\end{array}$ & -75.50 & $\begin{array}{l}\text { Six transmembrane epithelial antigen of the prostate } 1 \\
\text { (STEAP1), mRNA }\end{array}$ & -10.48 \\
\hline $\begin{array}{l}\text { Erythrocyte membrane protein band 4.1-like } 3 \text { (EPB41L3), } \\
\text { mRNA }\end{array}$ & -64.19 & Olfactomedin-like 2B (OLFML2B), mRNA & -10.40 \\
\hline Cartilage oligomeric matrix protein (COMP), mRNA & -53.13 & Secreted frizzled-related protein 4 (SFRP4), mRNA & -10.20 \\
\hline Proenkephalin (PENK), mRNA & -52.67 & Periostin, osteoblast specific factor (POSTN), mRNA & -9.99 \\
\hline Cholesterol 25-hydroxylase (CH25H), mRNA & -42.80 & HWKM1940 (UNQ1940), mRNA & -9.89 \\
\hline Procollagen C-endopeptidase enhancer 2 (PCOLCE2), mRNA & -39.29 & $\begin{array}{l}\text { Brain and acute leukemia, cytoplasmic (BAALC), } \\
\text { transcript variant } 2, \text { mRNA }\end{array}$ & -9.86 \\
\hline Alkaline phosphatase, liver/bone/kidney (ALPL), mRNA & -37.73 & $\begin{array}{l}\text { Amyloid beta (A4) precursor protein-binding, family B, } \\
\text { member } 1 \text { interacting protein (APBB 1IP), mRNA. }\end{array}$ & -9.76 \\
\hline Peptidase inhibitor 16 (PI16), mRNA & -25.70 & Tenascin C (hexabrachion) (TNC), mRNA & -9.71 \\
\hline Fibronectin type III domain containing 1 (FNDC1), mRNA & -22.74 & $\begin{array}{l}\text { H19, imprinted maternally expressed untranslated mRNA } \\
\text { (H19) on chromosome } 11\end{array}$ & -9.70 \\
\hline $\begin{array}{l}\text { Gamma-aminobutyric acid (GABA) B receptor, } 2 \text { (GABBR2), } \\
\text { mRNA }\end{array}$ & -22.49 & Forkhead box F2 (FOXF2), mRNA & -9.61 \\
\hline Early B-cell factor 3 (EBF3), mRNA & -18.34 & $\begin{array}{l}\text { C1q and tumor necrosis factor related protein } 5 \\
\text { (C1QTNF5), mRNA }\end{array}$ & -9.33 \\
\hline Crystallin, alpha B (CRYAB), mRNA & -17.78 & $\begin{array}{l}\text { Peroxisome proliferative activated receptor, gamma } \\
\text { (PPARG), transcript variant 1, mRNA }\end{array}$ & -9.22 \\
\hline Transmembrane protein 119 (TMEM119), mRNA & -17.42 & $\begin{array}{l}\text { Chemokine (C-X-C motif) ligand } 12 \text { (stromal cell-derived } \\
\text { factor 1) (CXCL12), transcript variant 1, mRNA }\end{array}$ & -8.73 \\
\hline Heme oxygenase (decycling) 1 (HMOX1), mRNA & -15.29 & Cytokine receptor-like factor 1 (CRLF1), mRNA & -8.57 \\
\hline Asporin (LRR class 1) (ASPN), mRNA & -14.50 & $\begin{array}{l}\text { Heparan sulfate (glucosamine) 3-0-sulfotransferase 3A1 } \\
\text { (HS3ST3A1), mRNA }\end{array}$ & -8.31 \\
\hline Placenta-specific 9 (PLAC9), mRNA & -14.20 & Hyaluronan synthase 2 (HAS2), mRNA & -8.21 \\
\hline Interleukin 13 receptor, alpha 2 (IL13RA2), mRNA & -13.88 & Lysyl oxidase-like 3 (LOXL3), mRNA & -7.97 \\
\hline $\begin{array}{l}\text { Potassium channel, subfamily } \mathrm{K} \text {, member } 2 \text { (KCNK2), transcript } \\
\text { variant } 1 \text {, mRNA }\end{array}$ & -12.98 & Slit homolog 3 (Drosophila) (SLIT3), mRNA & -7.85 \\
\hline Ependymin related protein 1 (zebrafish) (EPDR1), mRNA & -12.95 & Integral membrane protein $2 \mathrm{~A}(\mathrm{ITM} 2 \mathrm{~A})$, mRNA & -7.43 \\
\hline Amphiphysin (AMPH), transcript variant 1, mRNA & -12.85 & T-box 15 (TBX15), mRNA & -7.37 \\
\hline RAB3A interacting protein (rabin3)-like 1 (RAB3IL1), mRNA & -12.74 & $\begin{array}{l}\text { Collectin sub-family member } 12 \text { (COLEC 12), transcript } \\
\text { variant I, mRNA }\end{array}$ & -7.24 \\
\hline Microfibrillar associated protein 5 (MFAP5), mRNA & -11.97 & Neurocalcin delta (NCALD), mRNA & -7.24 \\
\hline Iroquois homeobox protein 3 (IRX3), mRNA & -11.25 & Heat shock 27kDa protein 2 (HSPB2), mRNA & -7.16 \\
\hline
\end{tabular}

hAMSC, human amniotic membrane-derived mesenchymal stem cells; hADSC, human adipose tissue-derived mesenchymal stem cells.

Bioinformatics Resources ver. 6.7 database (http://david.abcc. ncifcrf.gov)에서로 기능별로 clustering한 결과[18] 골분화를 포함한 개 체발달과 세포이동에 관여하는 경로를 조절하는 유전자에서 유의한 변 화가 나타났다.

\section{고 찰}

본 연구에서 hAMSC는 세포의 형태, 증식능 및 표면항원의 발현양상
은 hADSC이다(Table 1, Figs. 1, 2A). 이는 본 실험에 사용한 태반 양 막유래 세포가 중간엽줄기세포의 기준에 부합함을 나타낸다[7].

그러나, hAMSC는 Shh의 억제제인 cyclopamine에 의한 세포증식억 제 감수성, 골 및 지방세포로의 분화능 및 종양성장 촉진효과 등에서 $\mathrm{hADSC}$ 와 유의한 차이를 나타내었다(Figs. 2B, 3-5). 서로 다른 조직에 서 유래한 중간엽줄기세포의 특성 차는 다양한 조직에서 보고된 바 있 다. ADSC는 골수유래 중간엽줄기세포에 비하여 신생혈관생성능이 높 고[9] 동일 환자의 골수에서 분리한 중간엽줄기세포가 ADSC보다 골세 포 분화능은 높고 지방세포 분화능은 낮음이 보고되었다[8]. 


\title{
KOREAN JOURNAL OF OBSTETRICS \& GYNECOLOGY
}

\author{
KJOG Vol. 54, No. 11, 2011
}

Table 3. Genes list up-regulated in hAMSC than hADSC

\begin{tabular}{|c|c|c|c|}
\hline Definition & Fold & Definition & Fold \\
\hline Carboxypeptidase A4 (CPA4), mRNA & 79.01 & Endothelin 1 (EDN1), mRNA & 14.29 \\
\hline biglycan (BGN), mRNA & 79.00 & $\begin{array}{l}\text { BTB (POZ) domain containing } 11 \text { (BTBD11), transcript } \\
\text { variant 1, mRNA }\end{array}$ & 13.55 \\
\hline Keratin 8 (KRT8), mRNA & 53.95 & Ovary-specific acidic protein (OSAP), mRNA & 13.24 \\
\hline $\begin{array}{l}\text { Transglutaminase } 2 \text { (C polypeptide, protein-glutamine-gamma- } \\
\text { glutamyltransferase) (TGM2), transcript variant 1, mRNA }\end{array}$ & 40.40 & Neurexin 3 (NRXN3), transcript variant alpha, mRNA & 13.23 \\
\hline LY6/PLAUR domain containing 1 (LYPD1), mRNA & 39.89 & Mab-21-like 2 (C. elegans) (MAB21L2), mRNA. & 13.23 \\
\hline Hyaluronan and proteoglycan link protein 1 (HAPLN1), mRNA & 38.02 & $\begin{array}{l}\text { Leukemia inhibitory factor (cholinergic differentiation } \\
\text { factor) (LIF), mRNA }\end{array}$ & 12.56 \\
\hline Regulator of G-protein signalling 4 (RGS4), mRNA & 37.24 & $\begin{array}{l}\text { ST6 (alpha-N-acetyl-neuraminyl-2,3-beta- galactosyl-1, } \\
\text { 3)-N-acetylgalactosaminide alpha-2,6-sialyltransferase } \\
5 \text { (ST6GALNAC5), mRNA }\end{array}$ & 12.51 \\
\hline Actin, gamma 2, smooth muscle, enteric (ACTG2), mRNA. & 29.53 & Phospholipase D family, member 5 (PLD5), mRNA & 12.51 \\
\hline Annexin A10 (ANXA10), mRNA & 29.10 & $\begin{array}{l}\text { Aldehyde dehydrogenase } 1 \text { family, member A1 } \\
\text { (ALDH1A1), mRNA. }\end{array}$ & 12.34 \\
\hline $\begin{array}{l}\text { Deiodinase, iodothyronine, type II (DIO2), transcript variant 3, } \\
\text { mRNA. }\end{array}$ & 26.38 & $\begin{array}{l}\text { Integrin, alpha } 3 \text { (antigen CD49C, alpha } 3 \text { subunit of } \\
\text { VLA-3 receptor) (ITGA3), transcript variant a, mRNA }\end{array}$ & 11.52 \\
\hline Keratin 19 (KRT19), mRNA & 25.63 & $\begin{array}{l}\text { Collagen, type IV, alpha } 5 \text { (Alport syndrome) (COL4A5), } \\
\text { transcript variant 3, mRNA }\end{array}$ & 11.19 \\
\hline DIRAS family, GTP-binding RAS-like 3 (DIRAS3), mRNA & 25.22 & $\begin{array}{l}\text { EGF-like repeats and discoidin I-like domains } 3 \text { (EDIL3), } \\
\text { mRNA }\end{array}$ & 10.59 \\
\hline Ephrin-B2 (EFNB2), mRNA & 23.66 & Annexin A8 (ANXA8), mRNA & 10.35 \\
\hline Interleukin 1, beta (IL1B), mRNA & 22.05 & $\begin{array}{l}\text { Integrin, alpha } 2 \text { (CD49B, alpha } 2 \text { subunit of VLA-2 } \\
\text { receptor) (ITGA2), mRNA }\end{array}$ & 10.29 \\
\hline Junction plakoglobin (JUP), transcript variant 2, mRNA & 20.62 & $\begin{array}{l}\text { V-yes-1 Yamaguchi sarcoma viral related oncogene } \\
\text { homolog (LYN), mRNA }\end{array}$ & 10.29 \\
\hline Annexin A3 (ANXA3), mRNA & 18.05 & Neurotrophin 3 (NTF3), mRNA & 10.14 \\
\hline bradykinin receptor B1 (BDKRB1), mRNA & 16.73 & $\begin{array}{l}\text { Cyclin-dependent kinase inhibitor 2B (p15, inhibits } \\
\text { CDK4) (CDKN2B), transcript variant 2, mRNA }\end{array}$ & 9.83 \\
\hline Keratin 18 (KRT18), transcript variant 2, mRNA. & 16.47 & $\begin{array}{l}\text { Solute carrier family } 14 \text { (urea transporter), member } 1 \\
\text { (Kidd blood group) (SLC14A1), mRNA }\end{array}$ & 9.77 \\
\hline $\begin{array}{l}\text { NACHT, leucine rich repeat and PYD (pyrin domain) containing } \\
1 \text { (NALP1), transcript variant 5, mRNA }\end{array}$ & 16.07 & Transmembrane protein 88 (TMEM88), mRNA & 9.26 \\
\hline Neuropilin (NRP) and tolloid (TLL)-like 2 (NETO2), mRNA & 15.99 & Transforming growth factor, beta 2 (TGFB2), mRNA & 9.25 \\
\hline Nuclear factor (erythroid-derived 2)-like 3 (NFE2L3), mRNA & 15.56 & $\begin{array}{l}\text { Rho GDP dissociation inhibitor (GDI) beta (ARHGDIB), } \\
\text { mRNA }\end{array}$ & 9.24 \\
\hline Laminin, alpha 5 (LAMA5), mRNA & 14.94 & $\begin{array}{l}\text { Aldo-keto reductase family } 1 \text {, member B10 (aldose } \\
\text { reductase) (AKR1B10), mRNA }\end{array}$ & 8.96 \\
\hline $\begin{array}{l}\text { ST3 beta-galactoside alpha-2,3-sialyltransferase } 5 \text { (ST3GAL5), } \\
\text { mRNA }\end{array}$ & 14.43 & $\begin{array}{l}\text { Transcription factor AP-2 alpha (activating enhancer } \\
\text { binding protein } 2 \text { alpha) (TFAP2A), transcript variant 2, } \\
\text { mRNA }\end{array}$ & 8.73 \\
\hline
\end{tabular}

hAMSC, human amniotic membrane-derived mesenchymal stem cells; hADSC, human adipose tissue-derived mesenchymal stem cells.

최근 Shh가 중간엽줄기세포의 골세포 분화능을 억제하는 것으 로 보고되었다[19]. 따라서, cyclopamine에 대한 감수성을 감안할 때 $\mathrm{hAMSC}$ 에서 낮은 골세포 분화능이 이들 세포에서 상대적으로 높은 Shh 신호전달계와 부분적으로 관련 될 수 있다. hAMSC의 낮은 골세 포 및 지방세포 분화능은 관련 분야에서의 hAMSC의 조직공학적 사용
을 제한할 수 있다.

중간엽줄기세포의 중요한 응용분야는 암치료에의 적용이다. 실제로, 중간엽줄기세포에 발암 억제 유전자나 oncolytic virus 등을 탑재하여 효과적인 암치료효능을 나타낸 연구결과가 제시되고 있다[20,21]. 그 러나, 중간엽줄기세포가 암세포 미세환경을 제공하거나 신생혈관생성 


\section{KOREAN JOURNAL OF OBSTETRICS \& GYNECOLOGY}

In Seob Hwang, et al. Comparison with human amniotic membrane- and adipose tissue-derived mesenchymal stem cells

Table 4. Functional annotation clustering by DAVID bioinformatics

\begin{tabular}{|lcc|}
\hline Term & Count & $P$-value \\
\hline GO:0032502-developmental process & 195 & $1.55 \mathrm{E}-27$ \\
GO:0048731-system development & 159 & $9.70 \mathrm{E}-26$ \\
GO:0048856-anatomical structure development & 167 & $1.01 \mathrm{E}-25$ \\
GO:0048513-organ development & 121 & $1.80 \mathrm{E}-19$ \\
GO:0030154-cell differentiation & 91 & $7.05 \mathrm{E}-09$ \\
GO:0001944-vasculature development & 32 & $2.32 \mathrm{E}-11$ \\
GO:0048514-blood vessel morphogenesis & 25 & $2.27 \mathrm{E}-08$ \\
GO:0001525-angiogenesis & 18 & $2.27 \mathrm{E}-06$ \\
GO:0048646-anatomical structure formation involved in morphogenesis & 28 & $8.53 \mathrm{E}-06$ \\
GO:0001501-skeletal system development & 40 & $7.55 \mathrm{E}-14$ \\
GO:0001503-0ssification & 17 & $3.36 \mathrm{E}-07$ \\
GO:0001649-osteoblast differentiation & 7 & 0.001505 \\
GO:0030334-regulation of cell migration & 23 & $7.39 \mathrm{E}-09$ \\
GO:0040012-regulation of locomotion & 24 & $1.68 \mathrm{E}-08$ \\
GO:0051270-regulation of cell motion & 24 & $1.85 \mathrm{E}-08$ \\
\hline
\end{tabular}

DAVID, database for annotation, visualization and integrated discovery.

촉진, 면역억제 등을 통하여 암의 증식이나 전이를 촉진함이 알려져 임 상 적용 시 주의가 요구되고 있다[22,23]. 본 연구에서 관찰된 hAMSC 의 상대적으로 낮은 종양성장 촉진효과는 이들 세포가 암치료나 잠재적 종양을 가진 환자의 세포치료에 유용하게 사용될 수 있음을 제시한다.

성체조직유래 중간엽줄기세포에 비해 hAMSC는 자가세포를 얻을 수 없는 문제가 있다. 태아유래 양막세포는 HLAA-B-C (class la), HLADR (class II) 및 T lymphocyte costimulatory molecule인 B-7을 발현 하지 않아[24] 낮은 면역성과 면역조절기능을 가지며, 이는 본 연구의 유세포분석에서도 확인 되었다. 따라서, $\mathrm{hAMSC}$ 의 동종이식이 가능함 을 나타낸다.

본 연구에서 유전자 발현의 분석결과 유의한 차이를 나타내는 유전 자의 기능적인 분류를 실시한 결과 혈관 및 뼈를 포함한 발달과정과 세 포이동에 관여하는 유전자에서 발현차가 다수 관찰되었다(Table 4). 이 는 hAMSC가 hADSC보다 더욱 미분화상태를 유지할 가능성을 시사한 다. 또한, 골세포 분화능의 감소는 shh신호전달 뿐만 아니라 골모세포 의 분화에 관련된 유전자(BMP 2와 4 [25], HOXA2 [26], GPNMB [27], IGF2 및 IGFBP3 [28], IGFBP5 [29]) 및 그 외 다양한 골세포분화 관 련 유전자들(ALPL, AEBP1, THRA, PTGS2, EDN1, TGFB3, PRRX1, POSTN, PRRX2, HOXC9, HOXA5, COMP, HOXA10, HOXA9, AXIN2, GHR, COL 1OA1, TBX15, MGP, GAS1, CTSK, MSX1, HOXB7, HOXB8, CLEC3B, KAZALD1, HOXB6, SIX1, SORT1, TFAP2A, GDF10, FOXC1, STC1)의 변화로 설명할 수 있다. 개별 유전자의 변화와 hAMSC의 특 성간의 관련성은 추가 연구를 통해 밝혀져야 할 것이다.

본 연구결과는 서로 다른 조직에서 유래한 중간엽줄기세포의 특성차 이가 존재할 가능성을 제시하며, 이는 임상적용의 목적에 맞는 특성을
가진 중간엽줄기세포를 골라서 사용하는 것이 보다 나은 결과를 기대 할 수 있을 것임을 제시하였다.

\section{References}

1. Prockop DJ. Marrow stromal cells as stem cells for nonhematopoietic tissues. Science 1997;276:71-4.

2. Pittenger MF, Mackay AM, Beck SC, Jaiswal RK, Douglas R, Mosca JD, et al. Multilineage potential of adult human mesenchymal stem cells. Science 1999;284:143-7.

3. Baksh D, Song L, Tuan RS. Adult mesenchymal stem cells: characterization, differentiation, and application in cell and gene therapy. J Cell Mol Med 2004;8:301-16.

4. Herzog EL, Chai L, Krause DS. Plasticity of marrow-derived stem cells. Blood 2003;102:3483-93.

5. Lee KD, Kuo TK, Whang-Peng J, Chung YF, Lin CT, Chou SH, et al. In vitro hepatic differentiation of human mesenchymal stem cells. Hepatology 2004;40:1275-84.

6. Tropel P, Platet N, Platel JC, Noël D, Albrieux M, Benabid AL, et al. Functional neuronal differentiation of bone marrowderived mesenchymal stem cells. Stem Cells 2006;24:286876.

7. Dominici M, Le Blanc K, Mueller I, Slaper-Cortenbach I, Marini F, Krause $\mathrm{D}$, et al. Minimal criteria for defining multipotent mes- 


\title{
KOREAN JOURNAL OF OBSTETRICS \& GYNECOLOGY
}

\author{
KJOG Vol. 54, No. 11, 2011
}

enchymal stromal cells. The International Society for Cellular Therapy position statement. Cytotherapy 2006;8:315-7.

8. Sakaguchi Y, Sekiya I, Yagishita K, Muneta T. Comparison of human stem cells derived from various mesenchymal tissues: superiority of synovium as a cell source. Arthritis Rheum 2005;52:2521-9.

9. Kim Y, Kim H, Cho H, Bae Y, Suh K, Jung J. Direct comparison of human mesenchymal stem cells derived from adipose tissues and bone marrow in mediating neovascularization in response to vascular ischemia. Cell Physiol Biochem 2007;20:867-76.

10. Huang da W, Sherman BT, Lempicki RA. Systematic and integrative analysis of large gene lists using DAVID bioinformatics resources. Nat Protoc 2009;4:44-57.

11. Insausti CL, Blanquer M, Bleda P, Iniesta P, Majado MJ, Castellanos $G$, et al. The amniotic membrane as a source of stem cells. Histol Histopathol 2010;25:91-8.

12. Tamagawa T, Oi S, Ishiwata I, Ishikawa H, Nakamura Y. Differentiation of mesenchymal cells derived from human amniotic membranes into hepatocyte-like cells in vitro. Hum Cell 2007;20:77-84.

13. Wolbank $S$, Peterbauer A, Fahrner $M$, Hennerbichler $S$, van Griensven M, Stadler G, et al. Dose-dependent immunomodulatory effect of human stem cells from amniotic membrane: a comparison with human mesenchymal stem cells from adipose tissue. Tissue Eng 2007;13:1173-83.

14. Lin N, Tang Z, Deng M, Zhong Y, Lin J, Yang $X$, et al. Hedgehog-mediated paracrine interaction between hepatic stellate cells and marrow-derived mesenchymal stem cells. Biochem Biophys Res Commun 2008;372:260-5.

15. Chen JK, Taipale J, Cooper MK, Beachy PA. Inhibition of Hedgehog signaling by direct binding of cyclopamine to Smoothened. Genes Dev 2002;16:2743-8.

16. Valtieri M, Sorrentino A. The mesenchymal stromal cell contribution to homeostasis. J Cell Physiol 2008;217:296-300.

17. Yu JM, Jun ES, Bae YC, Jung JS. Mesenchymal stem cells derived from human adipose tissues favor tumor cell growth in vivo. Stem Cells Dev 2008;17:463-73.

18. Huang GT, Gronthos S, Shi S. Mesenchymal stem cells derived from dental tissues vs. those from other sources: their biology and role in regenerative medicine. J Dent Res 2009;88:792806.

19. Plaisant M, Fontaine C, Cousin W, Rochet N, Dani C, Peraldi P. Activation of hedgehog signaling inhibits osteoblast differentiation of human mesenchymal stem cells. Stem Cells 2009;27:703-13.

20. Yong RL, Shinojima N, Fueyo J, Gumin J, Vecil GG, Marini FC, et al. Human bone marrow-derived mesenchymal stem cells for intravascular delivery of oncolytic adenovirus Delta24-RGD to human gliomas. Cancer Res 2009;69:8932-40.

21. Grisendi G, Bussolari R, Cafarelli L, Petak I, Rasini V, Veronesi E, et al. Adipose-derived mesenchymal stem cells as stable source of tumor necrosis factor-related apoptosis-inducing ligand delivery for cancer therapy. Cancer Res 2010;70:3718-29.

22. Feng B, Chen L. Review of mesenchymal stem cells and tumors: executioner or coconspirator? Cancer Biother Radiopharm 2009;24:717-21.

23. Kuhn NZ, Tuan RS. Regulation of stemness and stem cell niche of mesenchymal stem cells: implications in tumorigenesis and metastasis. J Cell Physiol 2010;222:268-77.

24. Hunt JS, Petroff MG, McIntire RH, Ober C. HLA-G and immune tolerance in pregnancy. FASEB J 2005;19:681-93.

25. Chen D, Zhao M, Mundy GR. Bone morphogenetic proteins. Growth Factors 2004;22:233-41.

26. Dobreva G, Chahrour M, Dautzenberg M, Chirivella L, Kanzler $B$, Farinas I, et al. SATB2 is a multifunctional determinant of craniofacial patterning and osteoblast differentiation. Cell 2006;125:971-86.

27. Abdelmagid SM, Barbe MF, Arango-Hisijara I, Owen TA, Popoff SN, Safadi FF. Osteoactivin acts as downstream mediator of BMP-2 effects on osteoblast function. J Cell Physiol 2007;210:26-37.

28. Kveiborg M, Flyvbjerg A, Eriksen EF, Kassem M. 1,25-Dihydroxyvitamin D3 stimulates the production of insulin-like growth factor-binding proteins-2, -3 and -4 in human bone marrow stromal cells. Eur J Endocrinol 2001;144:549-57.

29. Mukherjee A, Rotwein P. Insulin-like growth factor-binding protein-5 inhibits osteoblast differentiation and skeletal growth by blocking insulin-like growth factor actions. Mol Endocrinol 2008;22:1238-50. 


\section{인체 양막과 지방조직에서 유래한 중간엽줄기세포의 특성 비교}

\section{부산대학교 의학전문대학원 산부인과학교실}

황인섭, 김휘곤, 조덕현, 이동형, 구윤희, 송용중, 나용진, 최욱환

목적

중간엽줄기세포는 면역거부반응이 적고 자가세포의 분리가 가능하여 세포치료를 위한 이상적인 줄기세포의 공급원로 간주되고 있다. 양 막에 중간엽줄기세포가 존재함이 보고되었으나, 이들 세포가 다른 조직에서 유래한 중간엽줄기세포와의 차이는 명확하게 밝혀져 있지 않 다. 본 연구는 인체 양막유래 중간엽줄기세포와 지방조직유래 중간엽줄기세포의 특성을 비교분석하고자 하였다.

\section{연구방법}

효소처리에 의해 분리 배양한 인체 양막유래 중간엽줄기세포와 지방조직유래 중간엽줄기세포의 특성을 세포성장, 표면항원발현, 세포분 화능, 종양증식능 및 유전자발현을 통하여 비교하였다.

결과

인체양막유래 중간엽줄기세포는 지방조직유래 중간엽줄기세포와 유사한 세포형태, 증식속도 및 표면항원의 발현양상은 나타내었으나, sonic hedgehog신호억제제인 cyclopamine은 양막유래 중간엽줄기세포만의 증식을 억제하였고 지방유래 중간엽줄기세포에 비해 낮은 지 방세포 및 골모세포로의 분화능을 나타내었으며, nude mouse에 이식한 폐암세포의 증식촉진작용에 있어서 양막유래 중간엽줄기세포가 지방조직유래 중간엽줄기세포보다 약한 효과를 나타냈었다. 또한, microarray로 측정한 유전자 발현양상에서 발달과 분화관련 유전자의 유의한 발현차가 확인되었다.

\section{결론}

이러한 결과는 양막유래 중간엽줄기세포와 성체조직유래 지방중간엽줄기세포 간의 특성차이를 밝힘으로서 임상적용목적에 따라 다양한 조직에서 분리한 중간엽줄기세포를 사용하는 것이 줄기세포를 이용한 세포치료에 도움이 될 수 있다는 것을 제시한다.

중심단어: 중간엽줄기세포, 인체 양막유래 중간엽줄기세포, 인체 지방조직유래 중간엽줄기세포 